\title{
PENGARUH EKSTRAK RANTING AGLAIA ODORATA LOUR. TERHADAP PERKEMBANGAN PARASITOID ERIBORUS ARGENTEOPILOSUS (CAMERON) PADA INANG CROCIDOLOMIA BINOTALIS ZELLER
}

\author{
Sudarmo $^{1}$, Djoko Prijono ${ }^{2}$, Syafrida Manuwoto ${ }^{2}$ dan Damayanti Buchori ${ }^{2}$
}

\begin{abstract}
The effect of Aglaia odorata Lour. twig extract on development of a parasitic wasp Eriborus argenteopilosus (Cameron) in its host Crocidolomia binotalis Zeller. This laboratory study was conducted to evaluate the effect of ethyl acetate soluble fraction of methanolic twig extract of Aglaia odorata Lour. (Meliaceae) on the development of a parasitic wasp Eriborus argenteopilosus (Cameron) (Hymenoptera: Ichneumonidae) in its host larvae Crocidolomia binotalis Zeller (Lepidoptera: Pyralidae). Extract treatment was given through the host. C. binotalis larvae were fed broccoli leaves treated with $A$. odorata extract at $\mathrm{LC}_{25}, \mathrm{LC}_{50}$, and $\mathrm{LC}_{70}$, then were exposed to the female adults $E$. argenteopilosus. Mortality of the parasitized host larvae, survival of immature stages of the parasitoid in the host larvae, and longevity and fecundity of the emerging female parasitoids were recorded. The results showed that combinations of extract treatments (at $\mathrm{LC}_{25}, \mathrm{LC}_{50}$, and $\left.\mathrm{LC}_{70}\right)$ and parasitization increased the mortality of the parasitized host larvae $(38,4-42,7 \%)$ more than twice that of the parasitized control larvae. Those extract treatments, however, did not exert any negative effects on developmental time of the parasitoid immature stages nor on some morphological characters, longevity and fecundity of the emerging female parasitoids. Thus, A. odorata extract showed promise to be integrated with the parasitoid for the control of C. binotalis.
\end{abstract}

Key words: Aglaia odorata, botanical insecticide, Crocidolomia binotalis, Eriborus argenteopilosus

\section{PENDAHULUAN}

Ulat krop kubis Crocidolomia binotalis Zeller (Lepidoptera: Pyralidae) merupakan salah satu hama penting pada pertanaman kubis yang dapat mengakibatkan kehilangan hasil sampai 65\% (Uhan, 1993). Di lapangan, pengendalian hama C. binotalis masih bertumpu pada penggunaan insektisida sintetik akibat ketiadaan musuh alami yang efektif dan keterbatasan cara-cara nonkimia lainnya (Sastrosiswojo \& Setiawati, 1992).

Musuh alami hama dari golongan parasitoid merupakan pilar pengendalian hama terpadu (PHT). Salah satu parasitoid larva $C$. binotalis yang sering dijumpai adalah Eriborus argenteopilosus (Cameron) (Hymenoptera: Ichneumonidae), tetapi tingkat keberhasilan parasitisasinya pada inang $C$. binotalis di lapang tidak mencapai 10\% (Othman, 1982). Rendahnya tingkat keberhasilan parasitisasi tersebut disebabkan oleh adanya enkapsulasi telur dan larva parasitoid di dalam tubuh inang (Hadi, 1985). Enkapsulasi merupakan penyelubungan benda asing yang berukuran relatif besar seperti telur atau larva parasitoid oleh struktur yang dibentuk oleh sel-sel darah tertentu dalam tubuh serangga inang yang dapat mengakibatkan kematian parasitoid (Gupta, 1991). Di laboratorium, enkapsulasi telur dan larva parasitoid $E$. argenteopilosus oleh inang $C$. binotalis mencapai lebih dari 90\% (Dono et al., 1998) sehingga hanya sebagian kecil parasitoid pradewasa yang dapat berkembang menjadi imago. Karena itu, upaya pengembangan sarana pengendalian yang secara efektif dapat menekan populasi hama tetapi dapat mempertahankan kelestarian musuh alami atau bahkan dapat meningkatkan kinerja musuh alami tersebut sangat penting untuk menunjang penerapan PHT.

Pada tulisan sebelumnya, Sudarmo et al. (2001) melaporkan bahwa ekstrak $A$. odorata memiliki daya bunuh yang baik terhadap larva $C$. binotalis tetapi cukup aman terhadap imago parasitoid $E$. argenteopilosus. Lebih lanjut dilaporkan bahwa perlakuan dengan ekstrak tersebut pada inang $C$. binotalis tidak berpengaruh terhadap parasitisasi inang

\footnotetext{
${ }^{1}$ Staf Pengajar pada Fakultas Pertanian, Universitas Darussalam Ambon

${ }^{2}$ Staf Pengajar pada Jurusan Hama dan Penyakit Tumbuhan, Fakultas Pertanian, Institut Pertanian Bogor
} 
tersebut oleh parasitoid E. argenteopilosus, dan bahkan dapat menekan enkapsulasi parasitoid tersebut oleh inangnya, sehingga dapat meningkatkan peluang parasitoid itu untuk berkembang di dalam tubuh inangnya. Namun, pengaruh yang tepat dari ekstrak A. odorata terhadap perkembangan dan kelangsungan hidup parasitoid pradewasa serta karakter morfologi imago belum pernah dilaporkan. Pengaruh negatif insektisida terhadap perkembangan, kelangsungan hidup, dan karakter morfologi dapat mengakibatkan rendahnya kapasitas reproduksi parasitoid (Kuo, 1986; Barbosa et al., 1991; Bentz \& Neal, 1995). Karena itu, meskipun insektisida botani $A$. odorata selektif terhadap hama sasaran, pengaruh insektisida botani tersebut terhadap perkembangan parasitoid perlu diteliti untuk menilai keserasiannya dengan parasitoid secara menyeluruh.

Penelitian ini bertujuan untuk menguji pengaruh ekstrak $A$. odorata terhadap perkembangan pradewasa E. argenteopilosus, serta karakter morfologi, lama hidup dan keperidian imago parasitoid yang muncul dari inang $C$. binotalis yang diberi perlakuan ekstrak.

\section{BAHAN DAN METODE}

\section{Pemeliharaan Serangga Uji Crocidolomia binotalis}

Serangga inang $C$. binotalis diperbanyak di Laboratorium Fisiologi dan Toksikologi Serangga, Jurusan Hama dan Penyakit Tumbuhan, IPB. Pemeliharaan serangga dilakukan pada suhu dan kelembaban kamar $\left(25\right.$ - $31^{\circ} \mathrm{C}$, RH 65 - 85\%). Larva diberi makan daun brokoli bebas pestisida (hasil perbanyakan sendiri) dan serangga dewasa diberi makan larutan madu 10\% yang diserapkan pada kapas menurut cara yang diuraikan oleh Basana \& Prijono (1994). Larva instar 1 awal (6 - 8 jam setelah menetas) digunakan untuk percobaan dan sebagian digunakan sebagai inang untuk pemarasitan oleh parasitoid E. argenteopilosus.

\section{Eriborus argenteopilosus}

Parasitoid E. argenteopilosus diperbanyak di laboratorium dari induk yang berasal dari lahan pertanaman kubis di daerah sekitar Cisarua dan Cibodas, Bogor dengan cara seperti yang diuraikan oleh Sudarmo et al. (2001). Imago parasitoid diberi makan larutan madu $20 \%$ pada kapas dan sebagai inang untuk pemarasitan digunakan larva $C$. binotalis instar 1 umur 1 hari dan larva instar 1 yang siap berganti kulit ke instar 2 .

\section{Ekstraksi}

Ranting $A$. odorata diperoleh dari daerah Parung Banteng, Bogor. Ranting dikeringudarakan kemudian dipotong kecil-kecil dan selanjutnya digiling. Serbuk ranting diekstrak dengan metanol dengan cara perendaman, dan ekstrak yang diperoleh dipisahkan dalam campuran etil asetat - air dengan cara seperti yang telah diuraikan sebelumnya (Sudarmo et al., 2001). Fraksi etil asetat yang diperoleh disimpan dalam lemari es $\left(\leq 4{ }^{\circ} \mathrm{C}\right)$ hingga saat digunakan.

\section{Metode Uji Hayati}

Pengaruh Ekstrak A. odorata Terhadap Mortalitas Larva Inang yang Terparasit dan Perkembangan E. argenteopilosus

Fraksi etil asetat dari ekstrak metanol ranting $A$. odorata diuji pada konsentrasi 0,053\%, 0,08\% dan $0,10 \%$, yang setara dengan $\mathrm{LC}_{25}, \mathrm{LC}_{50}$ dan $\mathrm{LC}_{70}$ terhadap larva inang $C$. binotalis berdasarkan pengujian dengan metode perlakuan pakan seperti yang telah dilaporkan sebelumnya (Sudarmo et al., 2001). Ekstrak dilarutkan dalam campuran aseton metanol (3:1), kemudian larutan ekstrak dioleskan secara merata dengan sonde mikro (microsyringe) pada kedua sisi potongan daun brokoli (diameter 3 $\mathrm{cm})$ sebanyak $25 \mu \mathrm{l} / \mathrm{sisi}$. Daun kontrol diolesi pelarut dengan volume yang sama. Satu potong daun perlakuan atau daun kontrol diletakkan dalam cawan petri (diameter $9 \mathrm{~cm}$ ) yang dialasi kertas hisap, kemudian ke dalam setiap cawan petri dimasukkan 20 larva $C$. binotalis instar 1 . Jumlah total larva pada setiap perlakuan diatur sedemikian rupa sehingga dapat diperoleh larva yang bertahan dalam jumlah yang cukup. Dari setiap konsentrasi perlakuan dan kontrol, 30 larva yang bertahan hidup dan siap ganti kulit ke instar 2 dipaparkan satu per satu pada seekor imago betina parasitoid yang telah kawin. Larva $C$. binotalis yang telah diparasit dipelihara dalam kotak plastik (15 cm x 11,5 cm x $6 \mathrm{~cm}$ ), sebanyak 30 larva per kotak, dan diberi makan daun brokoli bebas pestisida. Jumlah larva inang terparasit, lama perkembangan parasitoid pradewasa, serta jumlah pupa dan imago parasitoid yang terbentuk dicatat.

Percobaan disusun dalam rancangan acak lengkap (RAL) dengan enam ulangan. Semua data dalam persentase ditransformasi ke arcsin $\sqrt{ } \%$, kemudian diolah dengan sidik ragam, yang 
dilanjutkan dengan uji selang berganda Duncan untuk pembandingan nilai tengah antar perlakuan. Semua analisis statistika dilakukan menggunakan program SAS (SAS Institute, 1990).

\section{Pengaruh Ekstrak A. odorata Terhadap Lama} Hidup dan Keperidian E. argenteopilosus

Cara perlakuan dan konsentrasi ekstrak yang diuji sama seperti pada percobaan sebelumnya. Larva inang $C$. binotalis yang telah diparasit dipelihara dalam kotak plastik (35 cm x $25 \mathrm{~cm}$ x $6 \mathrm{~cm}$ ) dan diberi makan daun brokoli bebas pestisida. Imago betina parasitoid yang muncul dipelihara berpasangan dalam kurungan plastik - kasa (diameter $10 \mathrm{~cm}$, tinggi $25 \mathrm{~cm}$ ) dan diberi makan larutan madu 20\% yang diserapkan pada kapas. Ke dalam setiap kurungan setiap hari diumpankan 30 ekor larva C. binotalis instar 1 akhir untuk diparasit. Imago parasitoid mulai diberi umpan sejak berumur 1 hari setelah muncul sampai mati. Setelah 24 jam, larva inang $C$. binotalis yang telah diparasit dikeluarkan dari dalam kurungan dan dibedah di bawah mikroskop binokuler untuk menghitung jumlah telur parasitoid yang diletakkan. Parasitoid betina yang mati kemudian dibedah untuk melihat jumlah telur yang masih tersisa di dalam ovarinya. Lama hidup, lebar kapsul kepala, panjang sayap depan, dan panjang tibia tungkai belakang imago betina parasitoid juga dicatat. Percobaan ini dilakukan sampai diperoleh 15 ekor imago betina untuk setiap perlakuan dan kontrol. Analisis data seperti pada percobaan sebelumnya.

\section{HASIL}

\section{Pengaruh Ekstrak A. odorata terhadap Mortalitas Larva $C$. binotalis Terparasit}

Kombinasi perlakuan ekstrak A. odorata pada konsentrasi $0,053 \%, \quad 0,08 \%$ dan $0,10 \%$ dengan pemarasitan dapat meningkatkan mortalitas larva inang lebih dari dua kali dibandingkan mortalitas larva kontrol, tetapi antar perlakuan tidak terdapat perbedaan mortalitas yang nyata (Tabel 1). Tidak adanya perbedaan mortalitas antar perlakuan tersebut disebabkan karena larva yang digunakan adalah larva yang bertahan hidup setelah diberi perlakuan ekstrak selama 2 hari, dan hasil penelitian sebelumnya menunjukkan bahwa peningkatan mortalitas larva setelah hari ke-2 tidak jauh berbeda antar perlakuan konsentrasi ekstrak (Sudarmo et al., 2001). Dengan demikian dapat dikemukakan bahwa mortalitas larva C. binotalis dapat ditingkatkan dengan kombinasi perlakuan ekstrak $A$. odorata dan pemarasitan larva $C$. binotalis dengan parasitoid E. argenteopilosus.

Tabel 1. Pengaruh perlakuan ekstrak A. odorata yang diikuti pemarasitan oleh E. argenteopilosus terhadap mortalitas larva $C$. binotalis

\begin{tabular}{ccc}
\hline $\begin{array}{l}\text { Konsentrasi ekstrak } \\
(\%, \mathrm{v} / \mathrm{w})\end{array}$ & Jumlah larva inang & $\begin{array}{c}\text { Rataan mortalitas larva } \\
\text { inang } \pm \text { SB }(\%)^{1)}\end{array}$ \\
\hline $0(\text { kontrol })^{2)}$ & 178 & $19,1 \pm 8,3 \mathrm{a}$ \\
$0,053\left(\mathrm{LC}_{25}\right)$ & 175 & $38,4 \pm 8,7 \mathrm{~b}$ \\
$0,08 \quad\left(\mathrm{LC}_{50}\right)$ & 175 & $42,7 \pm 6,6 \mathrm{~b}$ \\
$0,10 \quad\left(\mathrm{LC}_{70}\right)$ & 175 & $41,3 \pm 22,3 \mathrm{~b}$ \\
\hline
\end{tabular}

1) Rataan yang diikuti oleh huruf yang sama tidak berbeda nyata (uji Duncan, $\alpha=0,05$ ).

2) Pemarasitan saja, tanpa perlakuan ekstrak. 
Tabel 2. Lama perkembangan parasitoid E. argenteopilosus pada inang C. binotalis yang diberi perlakuan ekstrak $A$. odorata

\begin{tabular}{ccc}
\hline $\begin{array}{c}\text { Konsentrasi ekstrak } \\
(\%, \mathrm{v} / \mathrm{w})\end{array}$ & \multicolumn{2}{c}{ Rataan lama perkembangan $\pm \mathrm{SB}\left(\right.$ hari) $(\mathrm{n})^{1)}$} \\
\cline { 2 - 3 } 0 (kontrol) & $15,0 \pm 0,7(43)$ & Betina \\
$0,053\left(\mathrm{LC}_{25}\right)$ & $15,7 \pm 0,9(46)$ & $16,0 \pm 1,0(25)$ \\
$0,08 \quad\left(\mathrm{LC}_{50}\right)$ & $15,4 \pm 0,7(23)$ & $16,0 \pm 0,5 \quad(8)$ \\
$0,10 \quad\left(\mathrm{LC}_{70}\right)$ & $14,7 \pm 0,6(25)$ & $15,3 \pm 0,9(12)$ \\
\hline
\end{tabular}

${ }^{1)} \mathrm{SB}$ : simpangan baku, n: jumlah imago parasitoid yang muncul.

Tabel 3. Kemunculan pupa dan imago parasitoid E. argenteopilosus pada inang C. binotalis yang diberi perlakuan ekstrak $A$. odorata

\begin{tabular}{cccccc}
\hline \multirow{2}{*}{$\begin{array}{c}\text { Konsentrasi } \\
\text { ekstrak } \\
(\%, \mathrm{v} / \mathrm{w})\end{array}$} & $\begin{array}{c}\text { Jumlah } \\
\text { larva } \\
\text { inang }\end{array}$ & $\begin{array}{c}\text { Rataan } \\
\text { pembentukan } \\
\text { pupa parasitoid } \\
\pm \text { SB (\%) }\end{array}$ & \multicolumn{2}{c}{$\begin{array}{c}\text { Rataan kemunculan } \\
\text { imago } \pm \text { SB }(\%)^{1)}\end{array}$} & $\begin{array}{c}\text { Rataan nisbah } \\
\text { imago betina } \\
\pm \text { SB (\%) }\end{array}$ \\
\hline 0 (kontrol) & 178 & $75,1 \pm 27,2$ & $44,7 \pm 10,5$ & $23,0 \pm 13,1$ & $30,8 \pm 16,0$ \\
$0,053\left(\mathrm{LC}_{25}\right)$ & 175 & $80,5 \pm 19,5$ & $51,9 \pm 15,9$ & $14,2 \pm 13,6$ & $18,4 \pm 14,9$ \\
$0,08 \quad\left(\mathrm{LC}_{50}\right)$ & 175 & $75,2 \pm 21,4$ & $36,1 \pm 33,5$ & $9,9 \pm 13,9$ & $20,3 \pm 28,1$ \\
$0,10 \quad\left(\mathrm{LC}_{70}\right)$ & 175 & $79,1 \pm 22,8$ & $24,1 \pm 15,6$ & $10,7 \pm 10,0$ & $33,1 \pm 36,8$ \\
\hline
\end{tabular}

1) Perbandingan jumlah imago yang muncul dengan jumlah pupa terbentuk. Hasil sidik ragam menunjukkan bahwa rataan pembentukan pupa dan kemunculan imago tidak berbeda nyata antar perlakuan (uji F, $\alpha=0,05$ ).

\section{Pengaruh Ekstrak A. odorata Terhadap Lama Perkembangan E. argenteopilosus}

Perlakuan ekstrak A. odorata pada konsentrasi 0,053\%, 0,08\% dan 0,10\% tidak berpengaruh nyata terhadap lama perkembangan parasitoid $E$. argenteopilosus menjadi imago jantan maupun betina (Tabel 2). Hal ini menunjukkan bahwa ekstrak tersebut tidak berpengaruh negatif terhadap parasitoid selama berkembang di dalam tubuh inangnya.

\section{Pengaruh Ekstrak A. odorata Terhadap Kemunculan Pupa dan Imago Parasitoid}

Pembentukan pupa parasitoid E. argenteopilosus tidak terhambat oleh perlakuan ekstrak $A$. odorata pada konsentrasi $0,053 \%, 0,08 \%$ dan $0,10 \%$. Sementara itu persentase kemunculan imago pada perlakuan ekstrak dengan konsentrasi 0,08\% ( $\left.\mathrm{LC}_{50}\right)$ dan 0,10\% (LC $\left.\mathrm{L}_{70}\right)$ tampak menurun meskipun secara statistika tidak berbeda nyata dengan kontrol (Tabel 3). Hal ini mungkin disebabkan oleh 
adanya residu senyawa aktif yang bersifat sitotoksik dalam tubuh inang atau parasitoid sehingga mempengaruhi pembentukan sel-sel serangga dewasa. Penurunan kemunculan imago parasitoid dapat berkaitan dengan nisbah kelaminnya sebab kemunculan imago jantan lebih tinggi dibandingkan kemunculan imago betina. Meskipun terjadi penurunan kemunculan imago, pada $\mathrm{LC}_{70}$ proporsi imago betina yang muncul tidak berbeda dengan kontrol. Hal ini disebabkan karena pada konsentrasi tersebut imago jantan lebih banyak mengalami kematian dibandingkan yang betina. Untuk memastikan penyebabnya, perlu dilakukan penelitian khusus yang terkait dengan hal tersebut.

\section{Pengaruh Ekstrak $A$. odorata terhadap Lama Hidup, Keperidian, dan Karakter Morfologi Imago Betina $E$. argenteopilosus}

Perlakuan ekstrak A. odorata pada konsentrasi 0,053, 0,08 dan 0,10\% tidak berpengaruh negatif terhadap lama hidup dan keperidian imago betina parasitoid, bahkan pada perlakuan konsentrasi $0,10 \%$ parasitoid tersebut cenderung memiliki lama hidup yang lebih panjang dan produksi telur yang lebih tinggi (Tabel 4).

Tabel 4. Lama hidup dan keperidian imago betina E. argenteopilosus yang muncul dari larva C. binotalis yang diberi perlakuan ekstrak A. odorata

\begin{tabular}{lrcc}
\hline $\begin{array}{c}\text { Konsentrasi ekstrak } \\
(\%, \mathrm{v} / \mathrm{w})\end{array}$ & $\mathrm{n}$ & $\begin{array}{c}\text { Lama hidup } \pm \text { SB } \\
\text { (hari) }\end{array}$ & $\begin{array}{c}\text { Rataan keperidian per betina } \\
\pm \text { SB (butir) }\end{array}$ \\
\hline $0($ Kontrol) & 15 & $5,4 \pm 4,0$ & $118,3 \pm 148,4$ \\
$0,053(\mathrm{LC} 25)$ & 15 & $6,1 \pm 3,7$ & $145,9 \pm 138,1$ \\
$0,08 \quad\left(\mathrm{LC}_{50}\right)$ & 8 & $4,6 \pm 4,8$ & $116,5 \pm 180,5$ \\
$0,10 \quad\left(\mathrm{LC}_{70}\right)$ & 14 & $7,7 \pm 5,6$ & $188,2 \pm 155,5$ \\
\hline
\end{tabular}

Hasil sidik ragam menunjukkan bahwa rataan lama hidup dan keperidian tidak berbeda nyata antar perlakuan (uji F, $\alpha=0,05$ ).

Tabel 5. Karakter morfologi imago betina E. argenteopilosus yang muncul dari larva C. binotalis yang diberi perlakuan ekstrak $A$. odorata

\begin{tabular}{crccc}
\hline \multirow{2}{*}{$\begin{array}{c}\text { Konsentrasi } \\
(\%, \mathrm{v} / \mathrm{w})\end{array}$} & $\mathrm{n}$ & $\begin{array}{c}\text { Kebar kapsul } \\
\text { kepala }\end{array}$ & Panjang sayap & $\begin{array}{c}\text { Panjang tibia } \\
\text { tungkai belakang }\end{array}$ \\
\cline { 3 - 5 } & & $1,78 \pm 0,07$ & $6,02 \pm 0,11$ & $2,04 \pm 0,06$ \\
$0($ Kontrol) & 15 & $1,81 \pm 0,03$ & $6,08 \pm 0,12$ & $2,06 \pm 0,08$ \\
$0,053\left(\mathrm{LC}_{25}\right)$ & 15 & $1,77 \pm 0,10$ & $6,02 \pm 0,24$ & $2,09 \pm 0,17$ \\
$0,08\left(\mathrm{LC}_{50}\right)$ & 8 & $1,75 \pm 0,08$ & $6,06 \pm 0,17$ & $2,10 \pm 0,09$ \\
$0,10\left(\mathrm{LC}_{70}\right)$ & 14 & 1,75 & \\
\hline
\end{tabular}

Hasil sidik ragam menunjukkan bahwa semua karakter morfologi yang diamati tidak berbeda nyata antar perlakuan (uji F, $\alpha=0,05$ ). 
Secara umum peletakan telur oleh imago betina parasitoid dalam tubuh inang mulai meningkat pada 2 hari setelah parasitoid muncul dari pupa. Peletakan telur pada hari pertama masih rendah, kemudian pada hari berikutnya mengalami peningkatan dan akhirnya menurun setelah hari ke-8, kecuali pada perlakuan konsentrasi $0,10 \%$ peletakan telur baru menurun setelah hari ke-11 (Gambar 1). Kebugaran parasitoid yang lebih baik pada perlakuan konsentrasi $0,10 \%$ $\left(\mathrm{LC}_{70}\right)$ mungkin disebabkan karena senyawa aktif dalam ekstrak $A$. odorata dapat menekan reaksi pertahanan inang terhadap parasitoid, yaitu menurunkan enkapsulasi parasitoid oleh larva inang
(Sudarmo et al., 2001), sehingga memberi peluang yang lebih besar bagi parasitoid untuk berkembang di dalam tubuh inangnya.

Perlakuan ekstrak A. odorata pada konsentrasi 0,053, 0,08 dan $0,10 \%$ juga tidak berpengaruh negatif terhadap karakter morfologi imago parasitoid yang mencerminkan bahwa parasitoid yang muncul dari inang yang diberi perlakuan ekstrak tidak mengalami gangguan morfologi. Imago yang muncul memiliki lebar kapsul kepala, panjang sayap, dan panjang tibia tungkai belakang yang tidak berbeda nyata dengan kontrol (Tabel 5).

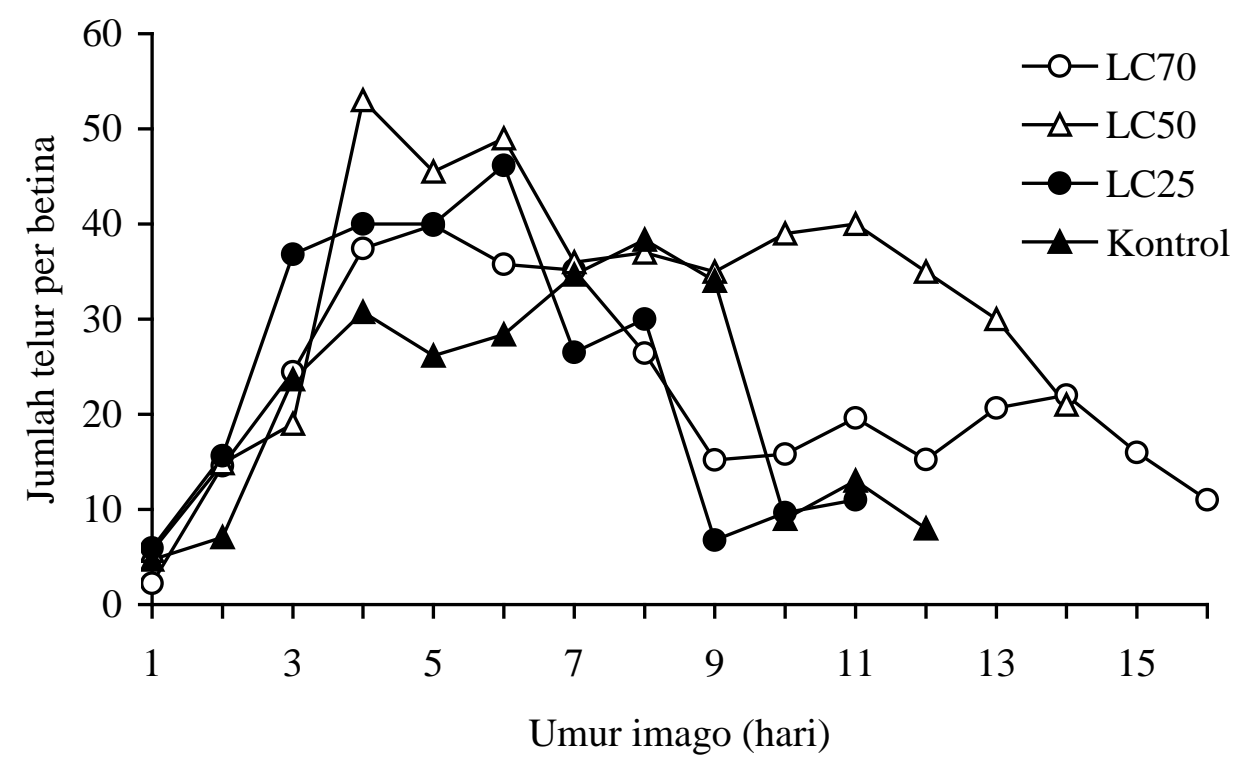

Gambar 1. Produksi telur harian E. argenteopilosus yang berkembang dari larva C. binotalis yang diberi perlakuan ekstrak A. odorata

\section{PEMBAHASAN}

Kombinasi perlakuan ekstrak $A$. odorata dengan pemarasitan oleh parasitoid E. argenteopilosus dapat meningkatkan mortalitas larva $C$. binotalis yang bertahan hidup dibandingkan perlakuan dengan ekstrak saja. Parasitoid pradewasa yang berkembang di dalam tubuh inang mengakibatkan kematian inang karena parasitoid pradewasa E. argenteopilosus memperoleh seluruh kebutuhan nutrisi dari inangnya. Selain itu, kondisi fisiologi larva inang yang sudah lemah akibat perlakuan ekstrak akan meningkatkan kematian larva inang.
Meskipun ekstrak $A$. odorata mempengaruhi lama perkembangan inang (Sudarmo et al., 2001), ekstrak tersebut tidak mempengaruhi lama perkembangan parasitoid dalam inang yang diberi perlakuan ekstrak. Hal ini mencerminkan bahwa parasitoid pradewasa dapat berkembang secara normal dalam tubuh inang. Perkembangan yang normal tersebut dapat terjadi mungkin karena reaksi pertahanan inang (berupa enkapsulasi parasitoid pradewasa oleh inang) dapat ditekan oleh perlakuan ekstrak (Sudarmo et al., 2001). Penekanan enkapsulasi memungkinkan telur dan larva parasitoid tumbuh dan berkembang dengan baik dalam tubuh 
inang. Hasil penelitian ini agak berbeda dengan hasil penelitian Campbell \& Duffey (1979) dan Barbosa et al. (1991) yang menunjukkan bahwa $\alpha$-tomatine dan nikotin yang ditambahkan dalam makanan inang masing-masing dapat memperpanjang lama perkembangan parasitoid Hyposeter exigua (Viereck) dan Cotesia congregata (Say) (Hymenoptera: Braconidae). Perbedaan tersebut kemungkinan disebabkan oleh perbedaan cara kerja senyawa yang digunakan. Nikotin dan $\alpha$-tomatine merupakan alkaloid yang dapat mempengaruhi sistem syaraf bukan hanya inang tetapi juga parasitoid yang terdapat di dalam tubuh inang tersebut, sedangkan senyawa aktif dalam ekstrak A. odorata - yaitu rokaglamida dan turunannya (Nugroho \& Proksch, 1999) — bukan racun syaraf dan tampaknya lebih menghambat fungsi sel-sel darah inang, misalnya dalam proses pembentukan kapsul (Sudarmo et al., 2001).

Perlakuan dengan ekstrak $A$. odorata tidak berpengaruh negatif terhadap pembentukan pupa parasitoid, mungkin karena residu senyawa aktif ekstrak di dalam tubuh inang tidak mencapai konsentrasi yang dapat mempengaruhi perkembangan parasitoid pradewasa selama di dalam tubuh inangnya. Selain itu, parasitoid pradewasa terhindar dari enkapsulasi oleh larva inang (Sudarmo et al., 2001) sehingga memungkinkan parasitoid terus berkembang sampai mencapai fase pupa.

Meskipun tidak berpengaruh negatif terhadap pembentukan pupa parasitoid, ada indikasi bahwa perlakuan dengan ekstrak $A$. odorata pada konsentrasi yang semakin tinggi cenderung menurunkan kemunculan imago parasitoid. Penurunan kemunculan imago yang terjadi mungkin disebabkan karena residu bahan aktif ekstrak yang terbawa pupa parasitoid cukup untuk menghambat pembentukan sel-sel imago. Hasil penelitian sebelumnya menunjukkan bahwa senyawa turunan rokaglamida bersifat toksik terhadap sel-sel kanker tertentu (King et al. 1982; Dumontet et al. 1996; Cui et al. 1997) dan secara spesifik dapat menghambat sintesis protein (Ohse et al., 1996).

Ekstrak $A$. odarata tidak berpengaruh negatif terhadap kebugaran imago parasitoid $E$. argenteopilosus yang muncul dari larva $C$. binotalis yang diberi perlakuan dengan ekstrak $A$. odorata, dalam hal karakter morfologi, lama hidup dan keperidian imago betina. Hal ini terjadi kemungkinan karena imago parasitoid yang muncul adalah individu yang dapat mengatasi pengaruh residu ekstrak yang terdapat dalam tubuh pupa, sementara individu yang rentan sudah mati pada fase pupa. Dengan demikian, ekstrak $A$. odorata memiliki potensi yang baik untuk digunakan sebagai salah satu sarana pengendali hama, khususnya $C$. binotalis, yang dapat dikombinasikan dengan penggunaan parasitoid.

\section{KESIMPULAN}

Perlakuan dengan ekstrak $A$. odorata yang diikuti dengan pemarasitan oleh parasitoid $E$. argenteopilosus dapat meningkatkan mortalitas larva C. binotalis yang bertahan hidup dibandingkan mortalitas akibat perlakuan dengan ekstrak saja, tetapi tidak berpengaruh negatif terhadap perkembangan dan kebugaran parasitoid tersebut, sehingga ekstrak $A$. odorata berpotensi untuk dipadukan dengan parasitoid E. argenteopilosus dalam pengendalian terhadap hama C. binotalis.

\section{SANWACANA}

Tulisan ini merupakan sebagian hasil penelitian yang dibiayai oleh RUT VI (1998/1999 1999/2000) kepada Djoko Prijono dkk. Ucapan terima kasih disampaikan kepada Agus Sudrajat atas bantuan pemeliharaan tanaman pakan serangga, serta M. Yusuf dan Endang Mustari atas bantuan pencarian parasitoid.

\section{DAFTAR PUSTAKA}

Barbosa, P., P. Gross \& J. Kemper. 1991. Influence of plant allelochemicals on the tobacco hornworm and its parasitoid, Cotesia congregata. Ecology 72: 15671575.

Basana, I.R. \& D. Prijono. 1994. Insecticidal activity of aqueous seed extracts of four species of Annona (Annonaceae) against cabbage head caterpillar, Crocidolomia binotalis Zeller (Lepidoptera: Pyralidae). Bul. HPT 7: 50-60.

Bentz, J. \& G. J. Neal. 1995. Effect of a natural insecticide from Nicotiana gossei on the whitefly parasitoid Encarsia formosa (Hymenoptera: Aphilenidae). J. Econ. Entomol. 88: 1611-1615.

Campbell, B.C. \& S.S. Duffey. 1979. Tomatine and parasitic wasps: potential incompatibility of plant antibiosis with biological control. Science 205: 700702. 
Cui, B., H. Chai, T. Santisuk, V. Reutrakul, N.R. Farnsworth, G.A. Cordell, J.M. Pezzuto \& A.D. Kinghorn. 1997. Novel cytotoxic $1 H$-cyclopenta[b] benzofuran lignans from Aglaia elliptica. Tetrahedron 35: 17625-17632

Dono, D., D. Prijono, S. Manuwoto \& D. Buchori. 1998. Pengaruh ekstrak biji Aglaia harmsiana Perkins terhadap interaksi antara larva Crocidolomia binotalis Zeller (Lepidoptera: Pyralidae) dan parasitoidnya, Eriborus argenteopilosus (Cameron) (Hymenoptera: Ichneumonidae). Bul. HPT 10: 38-46.

Dumontet, V., O. Thoison, O.R. Omobuwajo, M.T. Martin, G. Perromat, A. Chiaroni, C. Riche, M. Pais \& T. Sevenet. 1996. New nitrogenous and aromatic derivates from Aglaia argentea and A. forbesii. Tetrahedron 52: 6931- 6942.

Gupta, A.P. 1991. Insect immunocytes and other hemocytes: roles in cellular and humoral immunity. Pages 19-118 in: Gupta A.P. ed. Immunology of Insects and Other Arthropods: CRC Press, Boca Raton (Florida).

Hadi, S. 1985. Biologi dan perilaku Inareolata sp. (Hymenoptera: Ichneumonidae), parasitoid larva pada hama kubis Crocidolomia binotalis Zell. (Lepidoptera: Pyralidae) (Tesis). Fakultas Pascasarjana IPB, Bogor.

King, M.L., C.C. Chiang, H.C. Ling, O. Fujita \& A.T. McPhail. 1982. X-ray crystal structure of rocaglamide, a novel antileukemic $1 H$ cyclopenta[b]benzofuran from Aglaia elliptifolia. JCS Chem. Commun: 1150-1151.

Kuo, H.L. 1986. Resistance of oats to cereals aphids: effect on parasitism by Aphelinus asychis Walker). Pages 126-137 in: Boethel D.J. and R.D. Eikenbary RD eds. Interactions of Plant Resistance and
Parasitoids and Predators of Insects. Ellis Harwood, London. pp. 126-137.

Nugroho, B.W. \& P. Proksch. 1999. Insektisida botani dari tanaman Aglaia odorata (Meliaceae). Dalam: Prosiding Forum Komunikasi Ilmiah Pemanfaatan Pestisida Nabati, Bogor, $9 \quad-10$ November 1999.

Ohse, T., S. Ohba, T. Yamamoto, T. Koyano \& K. Umezawa. 1996. Cyclopenta-benzofuran lignan protein synthesis inhibitors from Aglaia odorata. J. Nat. Prod. 59: 650-652.

Othman, N. 1982. Biology of Crocidolomia binotalis Zell. (Lepidoptera: Pyralidae) and Its Parasites from Cipanas Area, West Java (a report of a training course research). SEAMEO Regional Centre for Tropical Biology, Bogor.

SAS Institute. 1990. SAS User's Guide, version 6, 4th ed,, vol. 2. SAS Institute Inc., Cary (North Carolina).

Sastrosiswojo, S. \& W. Setiawati. 1992. Biology and control of Crocidolomia binotalis in Indonesia. Pages 81-87 in: Talekar N.S. ed. Diamondback Moth and Other Crucifer Pests, Proc. Second Int. Workshop, Tainan, Taiwan, AVRDC, Taipei (Taiwan). 10-14 Dec. 1990.

Sudarmo, D. Prijono, S. Manuwoto \& D. Buchori. 2001. Selektivitas ekstrak ranting Aglaia odorata Lour. (Meliaceae) terhadap Crocidolomia binotalis Zeller dan parasitoidnya, Eriborus argenteopilosus (Cameron). Hayati (in press).

Uhan, T.S. 1993. Kehilangan hasil panen kubis karena ulat krop kubis (Crocidolomia binotalis) dan cara pengendaliannya. J. Hort. 3: 22-26. 
Tabel 1. Pengaruh perlakuan ekstrak A. odorata yang diikuti pemarasitan oleh E. argenteopilosus terhadap mortalitas larva $C$. binotalis

\begin{tabular}{ccc}
\hline $\begin{array}{l}\text { Konsentrasi ekstrak } \\
(\%, \mathrm{v} / \mathrm{w})\end{array}$ & Jumlah larva inang & $\begin{array}{c}\text { Rataan mortalitas larva } \\
\text { inang } \pm \mathrm{SB}(\%)^{1)}\end{array}$ \\
\hline $0(\mathrm{kontrol})^{2}$ & 178 & $19,1 \pm 8,3 \mathrm{a}$ \\
$0,053\left(\mathrm{LC}_{25}\right)$ & 175 & $38,4 \pm 8,7 \mathrm{~b}$ \\
$0,08\left(\mathrm{LC}_{50}\right)$ & 175 & $42,7 \pm 6,6 \mathrm{~b}$ \\
$0,10\left(\mathrm{LC}_{70}\right)$ & 175 & $41,3 \pm 22,3 \mathrm{~b}$ \\
\hline
\end{tabular}

1) Rataan yang diikuti oleh huruf yang sama tidak berbeda nyata (uji Duncan, $\alpha=0,05$ ).

2) Pemarasitan saja, tanpa perlakuan ekstrak.

Tabel 2. Lama perkembangan parasitoid E. argenteopilosus pada inang C. binotalis yang diberi perlakuan ekstrak $A$. odorata

\begin{tabular}{ccc}
\hline $\begin{array}{c}\text { Konsentrasi ekstrak } \\
(\%, \mathrm{v} / \mathrm{w})\end{array}$ & \multicolumn{2}{c}{ Rataan lama perkembangan $\pm \mathrm{SB}\left(\right.$ hari) $(\mathrm{n})^{1)}$} \\
\cline { 2 - 3 } $0($ kontrol$)$ & $15,0 \pm 0,7(43)$ & Betina \\
$0,053\left(\mathrm{LC}_{25}\right)$ & $15,7 \pm 0,9(46)$ & $16,0 \pm 1,0(25)$ \\
$0,08 \quad\left(\mathrm{LC}_{50}\right)$ & $15,4 \pm 0,7(23)$ & $16,0 \pm 0,5 \quad(8)$ \\
$0,10 \quad\left(\mathrm{LC}_{70}\right)$ & $14,7 \pm 0,6(25)$ & $15,3 \pm 0,9(12)$ \\
\hline
\end{tabular}

1) SB: simpangan baku, n: jumlah imago parasitoid yang muncul. 
Tabel 3. Kemunculan pupa dan imago parasitoid E. argenteopilosus pada inang C. binotalis yang diberi perlakuan ekstrak $A$. odorata

\begin{tabular}{|c|c|c|c|c|c|}
\hline \multirow{2}{*}{$\begin{array}{c}\text { Konsentrasi } \\
\text { ekstrak } \\
(\%, \mathrm{v} / \mathrm{w})\end{array}$} & \multirow{2}{*}{$\begin{array}{l}\text { Jumlah } \\
\text { larva } \\
\text { inang }\end{array}$} & \multirow{2}{*}{$\begin{array}{c}\text { Rataan } \\
\text { pembentukan } \\
\text { pupa parasitoid } \\
\pm \text { SB }(\%)\end{array}$} & \multicolumn{2}{|c|}{$\begin{array}{l}\text { Rataan kemunculan } \\
\text { imago } \pm \text { SB }(\%)^{1)}\end{array}$} & \multirow{2}{*}{$\begin{array}{l}\text { Rataan nisbah } \\
\text { imago betina } \\
\pm \text { SB (\%) }\end{array}$} \\
\hline & & & Jantan & Betina & \\
\hline 0 (kontrol) & 178 & $75,1 \pm 27,2$ & $44,7 \pm 10,5$ & $23,0 \pm 13,1$ & $30,8 \pm 16,0$ \\
\hline $0,053\left(\mathrm{LC}_{25}\right)$ & 175 & $80,5 \pm 19,5$ & $51,9 \pm 15,9$ & $14,2 \pm 13,6$ & $18,4 \pm 14,9$ \\
\hline $0,08 \quad\left(\mathrm{LC}_{50}\right)$ & 175 & $75,2 \pm 21,4$ & $36,1 \pm 33,5$ & $9,9 \pm 13,9$ & $20,3 \pm 28,1$ \\
\hline $0,10 \quad\left(\mathrm{LC}_{70}\right)$ & 175 & $79,1 \pm 22,8$ & $24,1 \pm 15,6$ & $10,7 \pm 10,0$ & $33,1 \pm 36,8$ \\
\hline
\end{tabular}

1) Perbandingan jumlah imago yang muncul dengan jumlah pupa terbentuk. Hasil sidik ragam menunjukkan bahwa rataan pembentukan pupa dan kemunculan imago tidak berbeda nyata antar perlakuan (taraf nyata 5\%).

Tabel 4. Lama hidup dan keperidian imago betina E. argenteopilosus yang muncul dari larva $C$. binotalis yang diberi perlakuan ekstrak $A$. odorata

\begin{tabular}{lccc}
\hline $\begin{array}{c}\text { Konsentrasi ekstrak } \\
(\%, \mathrm{v} / \mathrm{w})\end{array}$ & $\mathrm{n}$ & $\begin{array}{c}\text { Lama hidup } \pm \text { SB } \\
\text { (hari) }\end{array}$ & $\begin{array}{c}\text { Rataan keperidian per betina } \\
\pm \mathrm{SB} \text { (butir) }\end{array}$ \\
\hline $0($ Kontrol $)$ & 15 & $5,4 \pm 4,0$ & $118,3 \pm 148,4$ \\
$0,053\left(\mathrm{LC}_{25}\right)$ & 15 & $6,1 \pm 3,7$ & $145,9 \pm 138,1$ \\
$0,08 \quad\left(\mathrm{LC}_{50}\right)$ & 8 & $4,6 \pm 4,8$ & $116,5 \pm 180,5$ \\
$0,10 \quad\left(\mathrm{LC}_{70}\right)$ & 14 & $7,7 \pm 5,6$ & $188,2 \pm 155,5$ \\
\hline
\end{tabular}

Hasil sidik ragam menunjukkan bahwa rataan lama hidup dan keperidian tidak berbeda nyata antar perlakuan (taraf nyata 5\%). 
Tabel 5. Karakter morfologi imago betina E. argenteopilosus yang muncul dari larva C. binotalis yang diberi perlakuan ekstrak $A$. odorata

\begin{tabular}{ccccc}
\hline \multirow{2}{*}{$\begin{array}{c}\text { Konsentrasi } \\
(\%, \mathrm{v} / \mathrm{w})\end{array}$} & $\mathrm{n}$ & \multicolumn{3}{c}{ Karakter morfologi $\pm \mathrm{SB}(\mathrm{mm})$} \\
\cline { 3 - 5 } & & $\begin{array}{c}\text { Lebar kapsul } \\
\text { kepala }\end{array}$ & Panjang sayap & $\begin{array}{c}\text { Panjang tibia } \\
\text { tungkai belakang }\end{array}$ \\
\hline $0($ Kontrol $)$ & 15 & $1,78 \pm 0,07$ & $6,02 \pm 0,11$ & $2,04 \pm 0,06$ \\
$0,053\left(\mathrm{LC}_{25}\right)$ & 15 & $1,81 \pm 0,03$ & $6,08 \pm 0,12$ & $2,06 \pm 0,08$ \\
$0,08\left(\mathrm{LC}_{50}\right)$ & 8 & $1,77 \pm 0,10$ & $6,02 \pm 0,24$ & $2,09 \pm 0,17$ \\
$0,10 \quad\left(\mathrm{LC}_{70}\right)$ & 14 & $1,75 \pm 0,08$ & $6,06 \pm 0,17$ & $2,10 \pm 0,09$ \\
\hline
\end{tabular}

Hasil sidik ragam menunjukkan bahwa semua karakter morfologi yang diamati tidak berbeda nyata antar perlakuan (taraf nyata 5\%).

Gambar 1. Produksi telur harian E. argenteopilosus yang berkembang dari larva C. binotalis yang diberi perlakuan ekstrak A. odorata

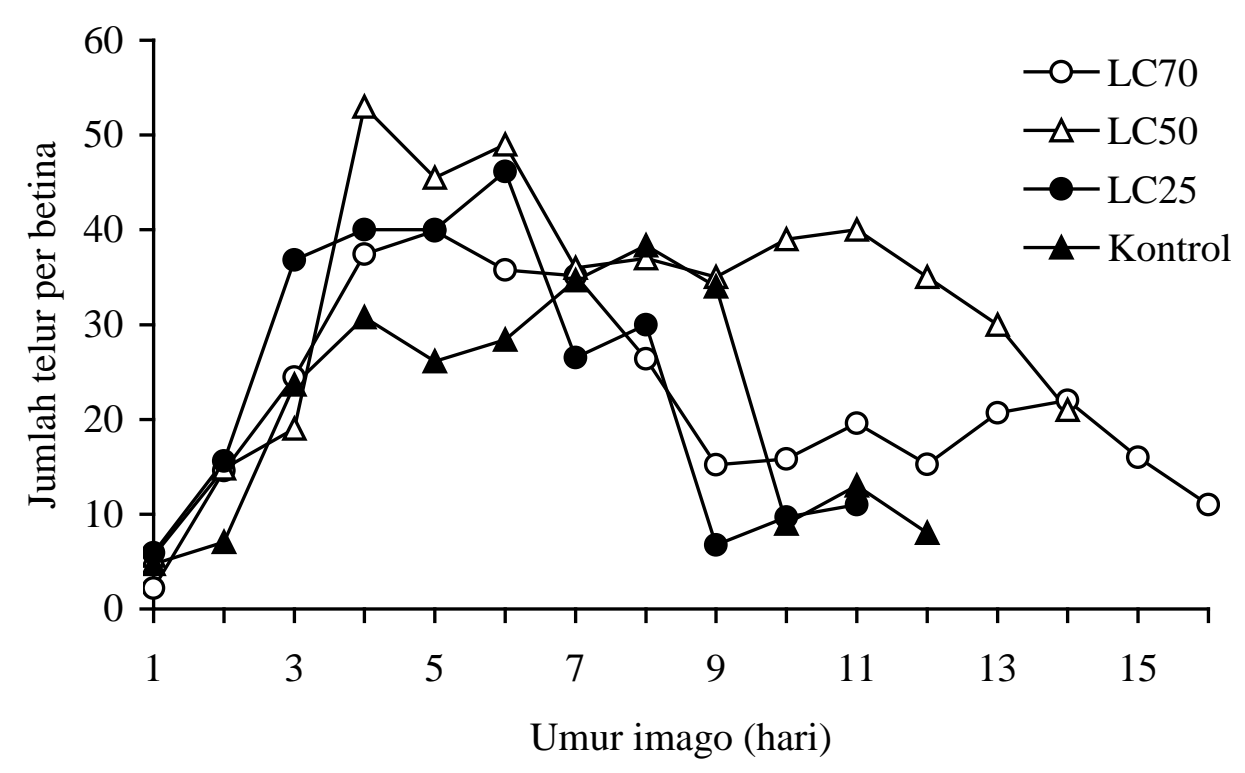

